\title{
Kabinet čudesa Šejkinog stvaralaštva
}
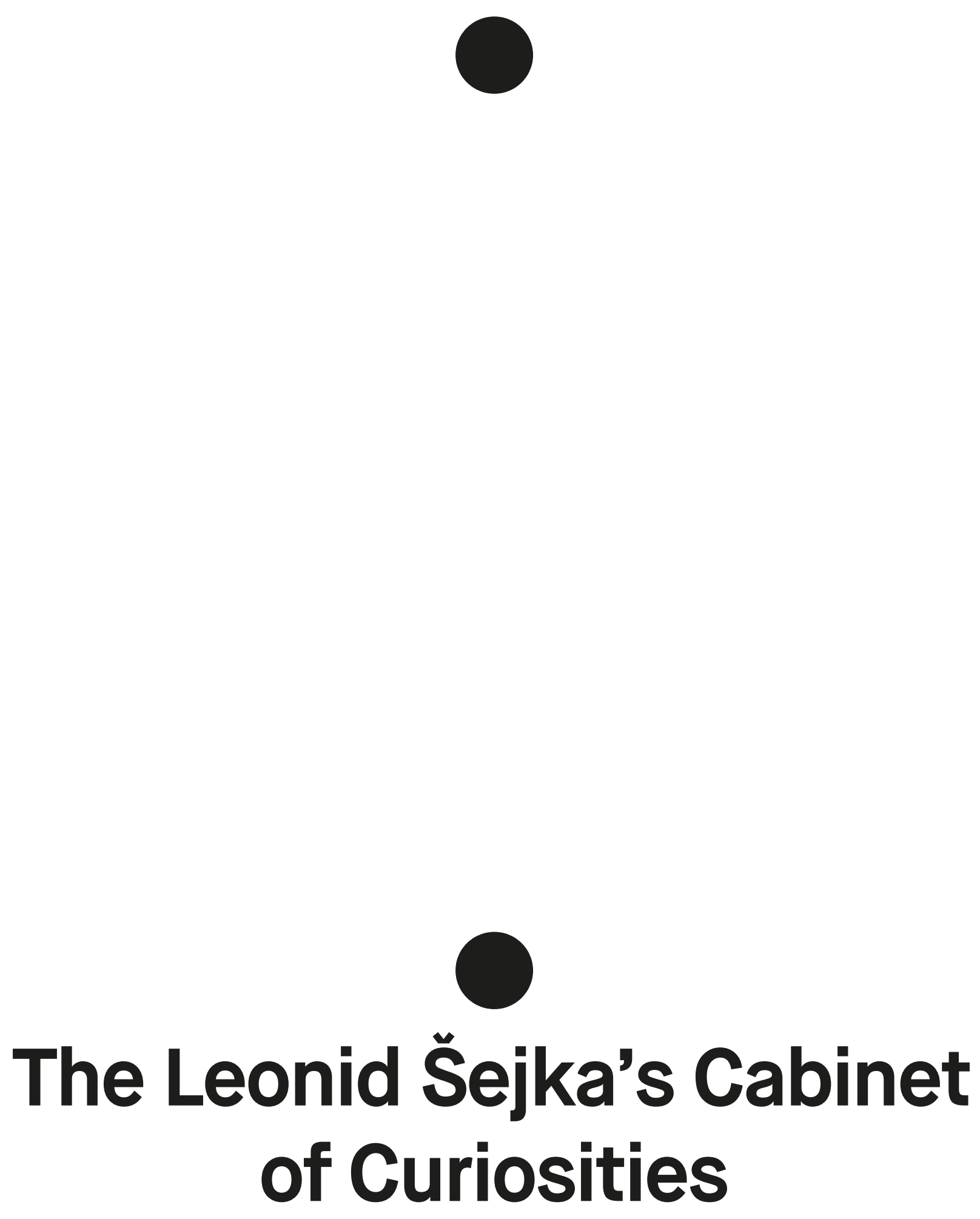
PREGLEDNI RAD

Primljen: 7. siječnja 2020.

Prihvaćen: 4. lipnja 2021.

DOI: 10.31664/zu.2021.108.04

\section{APSTRAKT}

Bogat opus likovnih dela, ali i literarni spisi umetnika Leonida

Šejke nastali su tokom pedesetih i šezdesetih godina 20. veka u Beogradu. Stvaralaštvo ovog umetnika, iako jednog od osnivača i aktivnih članova grupe Mediala, veoma je karakteristično i predstavlja jedinstvenu pojavu na čitavom jugoslovenskom prostoru ovog doba. Služeći se konceptom kabineta čudesa, fenomenom karakterističnim za rano moderno doba, u ovom radu ponudiće se jedno od mogućih tumačenja sveukupnog Šejkinog stvaralaštva i aktivnosti. Analizirajući njegova likovna dela, zapise i osvrćući se na neke od zaključaka istoričara umetnosti koji su se do sada bavili analizom pojedinačnih dela i serija radova, ili fenomena osobenih za njegovo stvaralaštvo, pokazaće se kako se Šejkin opus, te način života i razumevanja sveta, trebaju sagledati u celini, kao konstantan put ka kreiranju svojevrsnog modernog kabineta čudesa. Šejkino umetničko ponašanje uporedivo je sa pojedinim modernim umetnicima 20. veka i poetikama koje se neguju u kontekstu dadaizma i nadrealizma. Najzad, ovakav Šejkin pristup otvorio je put i mnogim savremenim umetnicima-kolekcionarima na prostorima bivše Jugoslavije, koji danas otvoreno koriste modele postavke kabineta čudesa.

KLJUČNE RIJEČI

Leonid Šejka, kabinet čudesa, kolekcija, predmet, đubrište

\section{REVIEW PAPER}

Received: January 1, 2020

Accepted: June 6, 2021

DOI: $10.31664 / z u .2021 .108 .04$

SUMMARY

A rich opus of artworks, but also the literary writings of the artist Leonid Šejka were created in Belgrade during the I950s and I960s. Although he was one of the founders and active members of the Mediala group, this artist's work is very characteristic and represents a unique phenomenon in the whole Yugoslav area of this period. Using the concept of the cabinet of curiosities (Wunderkammer), a phenomenon characteristic of the early modern age, this paper presents one of the possible interpretations of Šejka's overall creativity and activities. By analysing his artworks and writings, and referencing some of the conclusions of art historians who have interpreted his individual artworks and art series or phenomena specific to his work, this paper shows that Šejka's opus, way of life and understanding of the world should be viewed as a whole, as a constant path to creating some kind of a modern cabinet of curiosities. Šejka's artistic behaviour is comparable to the work of some modern artists of the 2oth century, and the poetics that were nurtured in the context of Dadaism and Surrealism. Finally, this approach of Šejka's opened the way for contemporary artists-collectors in the former Yugoslavia, who today openly use the settings of the cabinet of curiosities.

\section{Milena Jokanović}

Odeljenje za istoriju umetnosti, Filozofski fakultet Univerziteta u Beogradu

/ Art History Department, Faculty of Philosophy, University of Belgrade 
The first part of the paper defines the very notion of the cabinet of curiosities as a historical model of collecting, an assemblage of objects representing the microcosm, a picture of its creator's world, and gives a brief overview of this phenomenon as present in Renaissance and Baroque Europe, but also of its subsequent transformations caused by a change of attitude towards knowledge and the creation of modern museums and archives. However, the revived interest in pre-modern systems of collecting and representing knowledge in the early 20 th century encouraged art historians and critics to connect the cabinet of curiosities with some artistic avant-gardes of the 2oth century, which is when the work of artists like André Breton, Joseph Cornel land others was intensely interpreted and connected to this notion.

Another term. that needed to be defined more closely for further interpretation of Šjka's work is the notion of a garbage heap. Therefore, in the next segment of the text, the garbage heap is interpreted as a phenomenon of the consumer society, but also as a space for wandering for modern cityscape strollers who are ultimately the ones who collect discarded everyday objects from piles of garbage. The found objects are as often as not introduced into the art world by creative individuals to whom, as this paper demonstrates on the basis of the artist's artworks and writings, Šejka also belongs.

The paper further reveals several layers of how the models of collecting and arranging the collection, as well as the motives and meanings characteristic of historical cabinets of curiosities can be recognized in the work of this artist. The third part thus analyses an object, or rather a multitude of objects collected from the garbage heap as a significant starting point for Šejka's work, but also for his writing on art and other thoughts about the world he lived in, and that is why this artist can to some extent be compared to a Renaissance collector, someone who creates their image of the world with the help of various objects. This segment emphasizes the artist's need to embody his personal microcosm, both through groups of objects introduced into artworks such as those in the series Mrtva priroda [Still Life], Skladišta [Warehouses] and others, and through literary records of his reflections on the world and the symbolic value of objects in it. Finally, the paper reaches the conclusion that Šejka saw himself as a multiple personality dedicated to collecting, classifying and finally arranging his collection.

Another argument for applying the notion of the cabinet of curiosities to the interpretation of Šejka's opus is his attitude towards the Renaissance and the understanding of the world that is characteristic for that period. That is why this paper continues with an analysis of Šejka's return to the principles of Renaissance painting in his artworks such as the Soba [Room] series, of the use of motifs and symbolic elements characteristic of the early modern age, as well as the artist's opinion that the ideal world, closest to human needs, is to be found in the Renaissance and the principles of humanism.

Finally, the paper draws the conclusion that Šejka viewed his entire opus as a unity of his search for himself. For this artist, painting was ultimately a "technical means for marking, emphasizing and recording wondrous and significant phenomena in nature", and we cannot observe it as separate from Šejka's personality that is looking for such wonders in his environment and tried to present them in his painting. Thus Šejka's entire journey, each of his phases and systems, must be seen as a continuous ascent towards the goal (as the artist himself saw the exploration of the material world) of collecting and arranging into categories a series of sometimes very different, mutually juxtaposed objects in the collection, or rather the artist's expressions in painting, drawing and writing - which represent their creator's image of the world.

\section{KEYWORDS}

Leonid Šejka, cabinet of curiosities, collection, object, garbage heap 


\section{OTKRIĆE \\ RENESANSNIH KABINETA \\ ČUDESA U 20. VEKU}

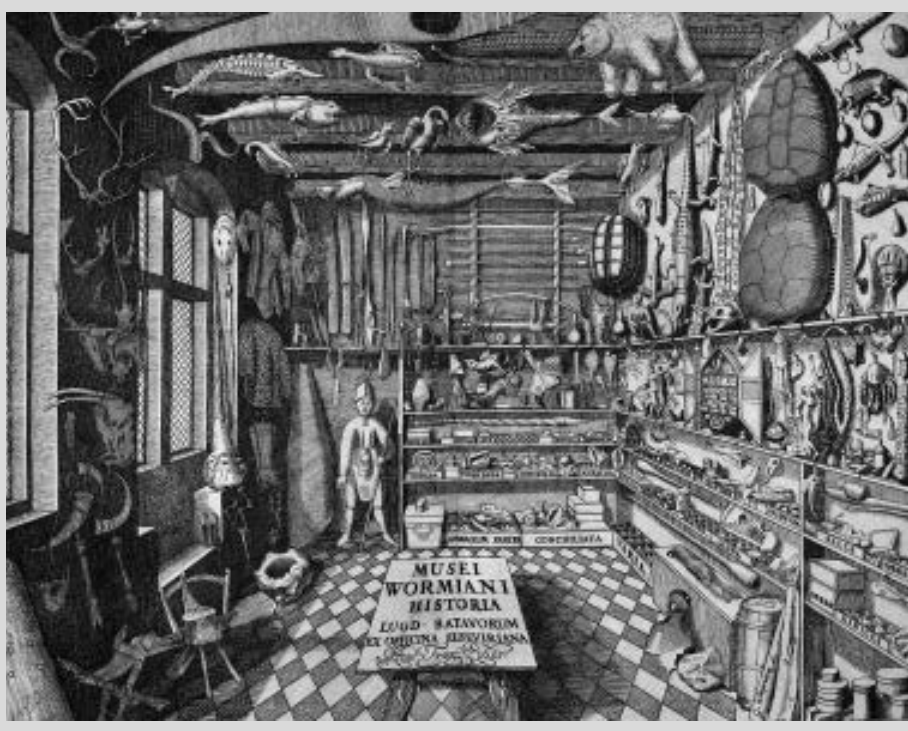

Frontispicij knjige Olea Worma Musei Wormiani Historia, Leiden, 1655. / The frontispiece of the book Musei Wormiani Historia, Leiden, 1655 by Ole Worm. (commons.wikimedia.org, https://wiki2.org/ en/File:Museum_Wormiani_Historia_1655_Wellcome_L0000128_.jpg) $\uparrow$

1

Rad jednim delom predstavlja daljim istraživanjem proširen segment doktorskog istraživanja koje je rezultovalo tezom: „Kabineti čudesa u svetu umetnosti: upotreba istorijskih modela kolekcioniranja u savremenoj umetničkoj praksi“ odbranjenom 20I8. godine na Filozofskom fakultetu Univerziteta u Beogradu.

Mauries, Cabinets of Curiosities, II9 [prev. aut.].

Na primer, spis Samuela von Kviheberga smatra se svojevrsnim protomuzeološkim spisom a sadrži preporuke za uređenje kabineta čudesa. Vidi: Quiccheberg Samuel von (I565), Inscriptiones vel Tituli Theatri Amplissimi Completentis (...), Munich: Adam Berg.

Ova teza zasnovana je na stanovištu Mišela Fukoa (Michel Foucault) predstavljenog u delu „Reči i stvari“, koje preuzima i muzeološkinja Ejlin Huper Grinhil (Eliean Hooper Greenhill), prilagođavajući uspostavljenu epistemologiju na primer nastanka i razvoja muzejskih kolekcija, od kabineta kurioziteta do modernih muzejskih institucija. Vidi: Hooper-Greenhill, Museums and Shapping of Knowledge. 5

Više o ovoj temi u navedenoj studiji E. Hooper-Greenhil. Isto. 6

Museums, their history and their use: with a bibliography and list of museums in the United Kingdom by David Murray, Glasgow: J. MacLehose and sons, 1904.; Die Kunst-und Wunderkammern der Spätrenaissance: ein Beitrag zur Geschichte des Sammelwessens von Julius von Schlosser, Leipzig: Klinkhardt \& Biermann, I908. 7

Manirizam kao istorijskoumetnički pojam i temu uvodi Jakov Burkhart (Jacob Burckhardt) početkom 20. veka a ubrzo ga prihvataju nemački istoričari umetnosti. U kontekstu ove teme pažnju možemo obratiti na to kako ovaj pojam afirmiše Gustav Rene Hoke (Gustav René Hocke), u svojoj studiji: Svet kao lavirint: manir i manija u evropskoj umetnosti 1957. godine (Die Welt als Labyrinth: Manier und Manie in der europäischen Kunst, Rowohlts Deutsche Enzyklopädie, vol. 50-5I. Hamburg: Rowohlt, 1957.)
Veličanstvene kolekcije najrazličitijih predmeta, kabineti čudesa odnosno kurioziteta, bili su veoma zastupljeni u zapadnoj Evropi tokom perioda renesanse i baroka. ${ }^{1} \mathrm{Na}$ istom mestu bile su sakupljene umetnine i antikviteti, uzorci flore i faune, različite kreacije čoveka, kao i pisana građa, sačinjavajući celinu namenjenu eruditskom izučavanju, ali i reprezentaciji vlasnika. Ovi nagomilani predmeti mogli su biti izloženi u vitrini, posebnoj kutiji, radnoj sobi ili pak u čitavim zamcima velikih vladara.

Ključne razloge za težnju kolekcionara da „ukroti i sebi podredi" vreme i okruženje objasniće Patrik Moris (Patrick Maurice): „Centralno za tezu koja potcrtava kabinete kurioziteta, kao i bilo koju kolekciju jeste upravo zaustaviti protok vremena, zamrznuti neizbežni napredak života ili istorije, i zameniti ga fragmentiranim, kontrolisanim kružnim vremenskim okvirom uspostavljenim konačnim nizom u celosti sakupljenih predmeta. Podređen opštem poretku stvari, ovaj vremenski okvir otkriva ostrvo smisla smešteno usred okeana lišenog značenja. " ${ }^{2}$ Otkrivajući melanholiju svakog kolekcionara koji nikada ne uspeva da dovrši svoju kolekciju, već nastavlja da luta i istražuje svet ne bi li ga saznao, ova „ostrva smisla", iako naizgled veoma haotične kolekcije, imala su jasne kriterijume po kojima su bile uređena. ${ }^{3}$ Jukstapozicije predmeta podsticale su odabrane posmatrače na kako fizičko tako i mentalno lutalaštvo i otkrivale su odnos čoveka ranog modernog doba prema znanju i razumevanju sveta. ${ }^{4}$ Stoga se kabineti čudesa zajedno sa promenom odnosa prema znanju u vreme prosvetiteljstva transformišu u zbirke umetnina, minerala i prirodnih vrsta, tehničke zbirke i druge kolekcije modernih muzejskih institucija sa jedne strane, odnosno prostore za eksperiment i naučno otkriće s druge. ${ }^{5}$ Interesovanje za kolekcije kurioziteta i predmodernu estetiku čudesnog opet se javlja početkom 20. veka. Fenomen „ponovno otkriva" Dejvid Marej (David Murray) 1904. godine u svojoj studiji „Muzeji, njihova istorija i njihova upotreba", a zatim ga i Julije fon Šloser (Julius von Schlosser) obrađuje 1908. godine u studiji „Kabineti čudesa i umetnina kasne renesanse" ${ }^{6}$ što je uticalo ne samo na mnoge istoričare umetnosti i muzeologe, već i na umetnike tokom 20. veka. Oživljeni interes za kabinete čudesa, odnosno za predmoderne sisteme sakupljanja i reprezentacije znanja, prvenstveno u kontekstu istraživanja renesanse i manirizma, ${ }^{7}$ podstiče istoričare umetnosti i likovne kritičare da taj pojam (kabinet čudesa) povežu s nekim umetničkim avangardama 20. veka, posebno s nadrealističkim, dadaističkim i sličnim poetikama. Očito je da će duhovna klima postmodernih decenija pogodovati takvim tumačenjima, pa se tada stvaralaštvo umetnika poput Bretona (André Breton), Kornela (Joseph Cornell) i drugih intenzivno tumači i dovodi u vezu s ovim pojmom. Tako italijanska muzeološkinja, Adalđiza Lulji (Adalgisa Lugli), nakon što objavljuje rukopis „Prirodnine i čudesa" (Naturalia e Mirabillia) 1983. godine nudeći istorijsku perspektivu kabinetima čudesa, 
priređuje segment centralne izložbe sa temom „Umetnost i nauka" (Arte e scienza) na 42. bijenalu savremene umetnosti u Veneciji 1986. godine. Deo koji je ona kurirala nosio je naziv upravo „Wunderkammer" 8 odnosno „Kabinet čudesa". Bijenale 1986. godine je prva velika izložba savremene umetnosti 20. veka koja tendenciozno objednjuje nauku i umetnost otkrivajući neraskidive veze između istih. Lulji na izložbi Wunderkammer suprotstavlja istorijski kabinet čudesa delima umetnika nadrealizma i dadaizma te kutijama Džozefa Kornela, ističući vizuelne sličnosti između ovih i pokazujući da je nadahnuće za oba poteklo iz istih impulsa. ${ }^{9}$ Ovu tezu prihvatiće i drugi istoričari umetnosti baveći se analizom određenih Bretonovih, Dišanovih (Marcel Duchamp) i Kornelovih dela. ${ }^{10}$

\section{ĐUBRIS̆TE KAO \\ PROSTOR S̆EJKINOG ISTRAŽIVANJA I KOLEKCIONIRANJA}

Pored pojma kabneta čudesa, koji je dakle revalorizovan početkom 20. veka i naknadno doveden u vezu sa nadrealizmom i sličnim poetikama, za tumačenje Šejkinog stvaralaštva neophodno je bliže odrediti i pojam đubrišta. Naime, uz gradske pejzaže, đubrište kao fenomen potrošačkog društva modernom šetaču postaje prostor lutanja, istraživanja i otkrivanja, ali i simboličko mesto kraha svih vrednosti koje podstiče na preispitivanje i kritičko promišljanje sveta. Gomile, zbog prekomerne proizvodnje i česte zamene odbačenih objekata, postaju predmet interesovanja umetnika koji ih pronalaze, sakupljaju, ali i uvode u svet umetnosti ovim činom neretko kritikujući vladajuće sisteme vrednosti. ${ }^{11}$ Umetnici se ovakvim postupkom mogu porediti sa kreatorima nekadašnjih kabineta čudesa ili drugih (muzejskih) kolekcija u kojima su odabrani predmeti izdvojeni iz svog primarnog ili čak arheološkog konteksta, ${ }^{12}$ te rekontekstualizovani: oni više nemaju utilitarnu vrednost već onu dokumentarnu, svedočeći o stvarnosti koja se nalazi van okvira muzejske postavke. Lutalaštvo, otkrivanje značenja koje se nalazi iza samog predmeta, te sakupljanje i direktno proučavanje predmeta kako bi se razumeo svet, karakteristični su dakle i za period stvaranja preteča današnjih muzeja, kabineta čudesa, kao i za aktivnosti pomenutih umetnika. Dok šetači modernog doba lutajući gradom i đubrištem teže da razumeju haotičan svet svoje svakodnevice, renesansnog kolekcionara upravo putovanja i otkriće Novog, za njegov razum veoma začudnog sveta, ${ }^{13}$ podstiču na kreiranje ličnog mikrokosmosa otelovljenog u kolekciji kurioziteta. Ono što povezuje umetnike modernog doba sa nekadašnjim kreatorima kabineta čudesa jeste dakle sama praksa istraživanja lutanjem i sakupljanja predmeta kao epistemološka metoda.

O vrednosti predmeta u kulturi modernog doba na veoma interesantan način piše Majkl Tompson (Michael Thompson). Nalazeći polazište u teoriji katastrofe matematičara Renea Toma (René Thom), on 1979. godine uspostavlja takozvanu teoriju smeća (rubbish theory) u kojoj pravi razliku u načinima na koje predmeti mogu biti sagledani. Ovom autoru je čovek i njegov odnos prema materijalnoj kulturi u žiži interesovanja. U sebi savremenoj kulturi Tompson prepoznaje dve kategorije: „prelazne" (transient) i „trajne" (durable) predmete. Kako autor diskutuje, predmeti iz kategorije prelaznih vremenom gube na svojoj vrednosti, odnosno na značaju za čoveka, te imaju ograničen životni vek. S druge strane, predmeti koji pripadaju kategoriji trajnih dobijaju sve veću vrednost vremenom i u idealnom slučaju, imaju beskonačan životni vek. Mnoge poznate predmete baštine te objekte koji su pripadali vladarima, kao i one izrađene uz pomoć posebne virtuoznosti, autor svrstava u kategoriju trajnih. U oba slučaja, isključivo način na koji se čovek odnosi prema stvarima, svrstava iste u jednu ili u drugu kategoriju. Naime, kada se radi o predmetima, postoji veza između našeg pogleda na svet i naših ponašanja u tom svetu, kako Tompson zaključuje. Ipak, prema ovom autoru, svet predmeta ne iscrpljuju samo oni prelazni i trajni, već u ovom svetu on uočava i predmete takozvane nulte vrednosti koje naziva smećem i svrstava ih u treću kategoriju. Njegova hipoteza je da je ova prikrivena kategorija smeća nastala upravo opadanjem vrednosti prelaznih objekata, te njihovim odbacivanjem i pravljenjem đubrišta (čije je stvaranje, dakle, karakteristika modernog, industrijskog društva i obimne proizvodnje). U idealnom svetu, svi predmeti bi kada dostignu ovu nultu, bezvrednu tačku postali prašina i zauvek nestali, međutim, ono što se zapravo dešava jeste da oni nastavljaju da postoje u takozvanom bezvremenom i bezvrednosnom limbu (koji ponovo možemo prepoznati i kao oblik arheološkog konteksta predmeta u muzeološkoj teoriji) ako ih, nekada kasnije (ukoliko se isti zaista ne pretvori u prašinu) ne otkrije neki kreativni pojedinac i uspešno ne prevede u kategoriju trajnih predmeta. „Očaravajuća posledica ove hipoteze jeste da, ukoliko želimo da izučavamo društveno kontrolisanje vrednosti, moramo da izučavamo smeće", smelo zaključuje autor. ${ }^{14}$

Leonida Šejku, u ovom kontekstu, možemo shvatiti upravo kao „kreativnog pojedinca" koji prostor đubrišta vidi kao prostor slobode i beskrajnih mogućnosti. On u svojim tekstovima nastalim pre objašnjene teorije, uspostavlja premise analogne Tompsonovim: „(...) u svetu vidljivog priznajemo postojanje samo dve izolovane vrste predmeta-pojava: one koji su vezani za praktičnu funkciju i one koji su od nje slobodni." ${ }^{15}$ Svestan značaja kolekcije predmeta kao slike sveta on će zapisati i:
„Medutim, označavanje predmeta-pojave, kao i oblikovanja novih predmeta (ma koliko bio izmenjen čovekov odnos prema svetu), uvek znači projekciju čovekovog odnosa prema svetu. Predmet- - pojava, bilo postojeći u prirodi, bilo proizveden čovekovom akcijom, sa svojim značenjem koje postoji u obliku, oznaci i upotrebi, predstavlja otisak i nacrt čovekovih namera u smislu saznavanja, razumevanja sveta i sebe, i u smislu preobražavanja sveta, odnosno podešavanja sveta sebi. Bez obzira da li se u istorijskom razvitku odigrava polarizacija saznajnog i praktičnog, ili ponovna integracija, od časa kada čovek otkriva svet oko sebe i u sebi, 
Nemački termin Wunderkammer u literaturi se zadržao kao opšteprihvaćen.

Jokanović, „Memory on the Cabinets of Wonders in Modern Art“. 10

Vidi: Endt, Reopening the Cabinet of Curiosities:Nature and the Marvellous in Surrealism and Contemporary Art; Bowry, Re-thinking the Curiosity Cabinet: A Study of Visual Representation in Early and Post Modernity.

11

Autorka ovaj pojam i njegovo značenje preuzima iz institucionalne teorije umetnosti Džordža Dikija, te daljih razmišljanja o ovom pojmu koja nudi Artur Danto. Vidi: Dickie, Art and the Aesthetic: An Institutional Analysis; Danto, "The Artworld"; isti, The Transfiguration of the Commonplace: a Philosophy of Art.

12

Muzeolog Piter fan Menš (Peter van Mensch) određuje arheološki kontekst muzejskog predmeta kao privremeni ili stalni depozit odbačenih predmeta. Ovaj depozit može biti stabilan-ukoliko se radi o namernom pohranjivanju predmeta - gde autor navodi na primer jevrejsku kulturu pohranjivanja svetih spisa za koje se veruje da ne smeju biti uništeni-i nestabilan depozit u kojem se nađu vremenom svi predmeti koji bivaju zamenjeni naprednijim, novijim objektima, poput različitih tehničkih uređaja i sličnog. Van Menš, Ka metodologiji muzeologije.

13

Usp. Greenblatt, Marvelous Possessions: The Wonder of the New World. 14

Thompson, Rubbish Theory: the Creation and Destruction of Value, Iо: autorkin prevod originalne rečenice: "The delightful consequence of this hypothesis is that, in order to study the social control of value, we have to study rubbish."

15

Šjejka, Traktat o slikarstvu, 82 .

16

Isto, 83

17

Subotić, „Leonid Šejka: Podaci o ličnosti i delu“, 25.

Šejka, Grad, dubrište, zamak I, 68.

19

Esej „Nova predmetnost u slikarstvu“ objavljen je u navedenoj zbirci Šejkinih tekstova. Isto, 202-2I2.

20

Preuzeto od Irine Subotić koja ovaj iskaz pronalazi na jednom od malobrojnih sačuvanih listova iz izgubljene knjige „O đubrištu“ koju je Šejka zajedno sa arhitektom i grafičkim dizajnerm Slobodanom Mašićem spremao da objavi oktobra 1956. godine: Subotić, „Leonid Šejka: Podaci o ličnosti i delu“, 3I. odnosno stalnu koincidenciju ovih svetova na različtitim nivoima, svaki postojeći predmet- pojava jeste mogućnost aktivnosti (istraživačke i prakticne) prema tom predmetu-pojavi i pomoću predmeta-pojave. “16

Već se u prvim razgovorima nakon udruživanja umetnika u grupu koja će kasnije poneti naziv „Mediala“ može prepoznati početak Šejkinih istraživačkih lutanja i sakupljanja predmeta, koji će biti i jezgro njegovog stvaralaštva. Naime, iako je prva izložba na kojoj su radove izložili Dado Đurić, Uroš Tošković, Siniša Vuković, Leonid Šejka i drugi, održana u Domu Omladine u Beogradu 1953. godine, grupa formalno počinje da postoji 1957. godine kada je 28. septembra u Šejkinom stanu održan takozvani prvi sastanak prijatelja Baltazara. Kako zapisuje Irina Subotić na osnovu svedočenja umetnice Olje Ivanjicki, ovim imenom su umetnici iz grupe označavali figuru nepoznatog beskućnika koji je lutao gradom, i činio im se kao pravi, iskonski neopterećen čovek, odnosno simbol čoveka, „kreatura đubrišta". lako će grupa 24. novembra promeniti svoj naziv u „Mediala" prema imenu lista koji tada počinje da izdaje, te definisati svoja načela funkcionisanja i stvaralaštva, ${ }^{17}$ za Leonida Šejku ovaj pojam đubrišta i lutalaštva po istom ostaće ključan.

Đubrište za Šejku jeste prostor na kojem se u prašini odbačenih predmeta svakodnevice, „gomili kablova, šljunka, krpa, gvožđa, (...) katanaca, flaša, zdruzganog stakla, (...), brava, levkova, štipaljki, kišobana, ključeva..." ${ }^{18}$ može prepoznati ilustracija teze o hiperprodukciji u potrošačkom društvu o kojoj on piše u eseju „Nova predmetnost u slikarstvu". ${ }^{19}$ Inspirisan prostorom đubrišta, umetnik će stvoriti i mnoga likovna dela, odnosno izrodiće čitave teme (o kojima će reči biti nešto kasnije). Kako i sam navodi:
I šta je sad to što sam radio kao „dubrište“ na dubrištu? To je u stvari jedna igra koju sam izmislio za sebe (a možda i nisam samo ja). Moje „đubrište“ nisu ni slike ni tekstovi ni bilo sta drugo. Ali kao materijalni dokaz o radnjama na dubrištu ostalo je nešto slika, nešto malo fotografija, nešto beležaka, predmeta koje sam sam izradivao, predmeta koje sam sakupio (veći deo bačen je natrag na dubrište) i možda po neki svedok o tome da sam nešto radio nazivajući to „Đubrište" (većina misli da se radi o slikarskoj ,fazi “ sto je pogrešno)... ${ }^{20}$

Za Šejku je đubrište „prostor beskrajnog lutanja" na kojem su različite, nekada razumom teško pojmljive relacije moguće. Ovaj haos nagomilanih predmeta koji su izgubili svoju osnovnu funkciju, podstiče ga na razmišljanja o njihovoj vrednosti, značenjima i simbolici. Poput pominjanih Bretona, Kornela i drugih umetnika modernog doba, Šejka luta gradom, izlazi na obode istog i sakuplja predmete sa đubrišta, uvodeći ih zatim u svet umetnosti, ovim činom im dajući novu vrednost. 


\section{ŠEJKIN KABINET \\ ČUDESA KROZ PREDMETE \\ SVAKODNEVICE}

Za Leonida Šejku dakle predmet, odnosno mnoštvo na đubrištu sakupljenih predmeta predstavljaju značajno polazište za njegovo stvaralaštvo, ali i pisanje o umetnosti i razmišljanje o svetu u kom živi. Upravo zato ovog umetnika možemo donekle porediti sa renesansnim kolekcionarem, kreatorom svoje slike sveta uz pomoć različitih predmeta. U studiji 1990. godine, Kžištof Pomian (Krzysztof Pomian) sugeriše da kolekcije treba da budu sagledane kroz istoriju koncentrišući se na semiofore, odnosno predmete koji pored utilitarne vrednosti poseduju i spoljašnja, simbolička značenja. U različitim vremenima naravno, različiti predmeti postaju semiofore, te tako one mogu biti umetnička dela, relikvije prošlosti, predmeti nađeni u prirodnom okruženju i egzotičnom svetu, ali i mnogi drugi. ${ }^{21}$ Transformacija kolekcija i ulazak novih objekata u iste, tako sugerišu kulturne, istorijske i društveno-ekonomske promene. U Šejkinoj kolekciji, ulogu semiofora imaju odbačeni predmeti svakodnevice.

Nakon što ih otrgne iz "bezvremenog i bezvrednosnog limba" đubrišta, Šejka predmete sakuplja u svojim umetničkim delima, odnosno na različite načine odbačene predmete uvodi u svoje radove. Neki od njih nastaju od bukvalnih predmeta, pa tako kreira objekte i asamblaže, a neki od nacrtanih ili naslikanih. Već sredinom 1955. ovaj umetnik počinje da istražuje amorfne strukture: biljke, draperije, zgužvanu hartiju, razlivenu tečnost, kristalaste strukture, mikroorganizme, životinje, uvelo lišće, oblike truljenja i otpalog maltera na zidovima. Ovakve strukture Šejka "ugrađuje" u objekte-kutije koje se mogu dovesti u vezu sa kolekcijama nagomilanih predmeta, kako kabinetima čudesa tako i Kornelovim kutijama. Ipak nazivi ovih dela jasno ukazuju na same strukture predmeta za koje je umetnik veoma zainteresovan: Cilindrična pozicija, Zgift multiplex. Gomilanje istog i sličnog, ponavljanje predmeta, odnosno umnožavanje oblika crtanjem i slikanjem i najzad skladištenje predmeta svakodnevice, postupci su tipični za Šejkin rad koji se mogu definisati kao svojevrsna geologija đubrišta, ispitivanje bezobličnog, mrlja i strukura. Serija crteža Skladišta koja direktno, kako nazivom tako i vizuelno, ukazuje na njegovu poetiku sabiranja i nagomilavanja predmeta u delu, prema Irini Subotić predstavlja najznačajniji deo Šejkinog opusa: „Bogata asocijativna moć, povezivanje sveta privida i stvarnosti, apstraktnih misli i konkretnih predmeta, prožimanje ideja nauke, istorije, filozofije, religije, politike-kosmos jučerašnjice i današnjice; rađeni su sa izvanrednim osećanjem za artikulaciju prostora u kompoziciji koja svojom prenatrpanošću i bukvalno govori o problemu nagomilanog, s pedantnim osećajem materije." ${ }^{22}$ Predmet kod Šejke postaje predmet za sebe, otelovljenje materije u jedno određeno predmetno obličje, on biva prisutnost, stanje, činjenica, vešto će zaključiti Jerko Denegri. ${ }^{23}$

Šejkino interesovanje za strukturu i druge osobenosti predmeta, odnosno za svojstva koja isti imaju pored utilitarne funkcije, uviđaju se i u umetnikovom postupku „progla-

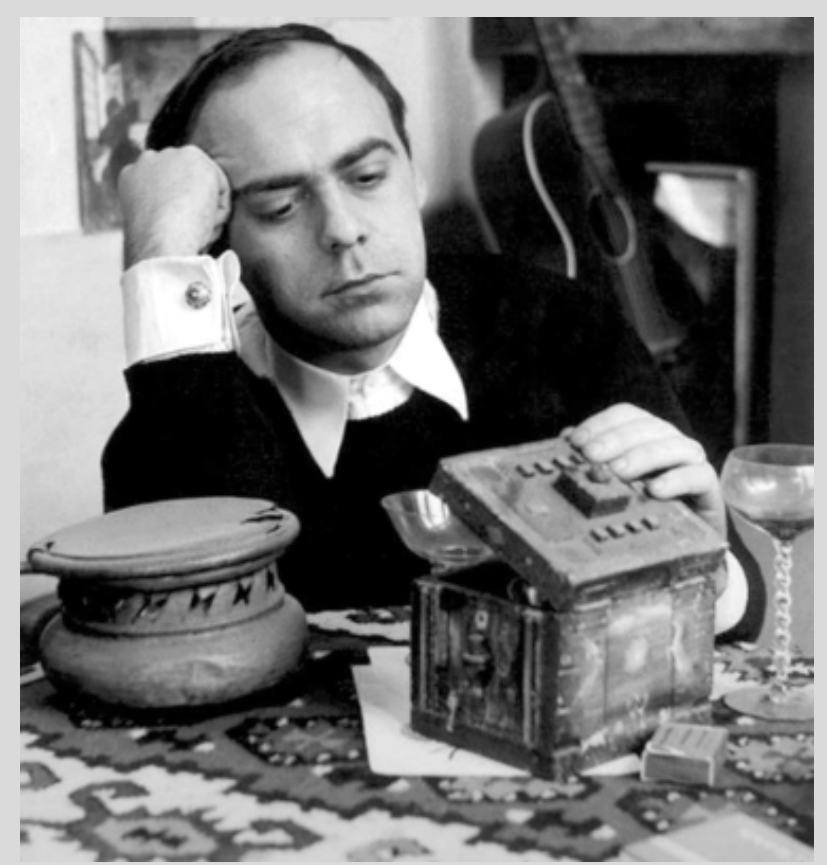

Portret Leonida Šejke / The portrait of Leonid Šejka, FOTO / РHOTO: Miodrag Đorđević $\uparrow$ 21

Pomian, "The Collection: between the Visible and the Invisible", passim. 22

Subotić, „Leonid Šejka: Podaci o ličnosti i delu“, 40. 23

Denegri, Srpska umetnot 1950-200o: Pedesete, I9.

\section{4}

Metlić, „U Šejkinoj zoni“, I55.

25

Merenik, Umetnost i vlast: srpsko slikarstvo 1945-1968, I4I.

26

Kao što je i prostor svakog kabineta čudesa a kasnije muzejske postavke zaseban svet koji funkcioniše u svojim okvirima i zakonitostima. 27

Šejka, Grad, dubrište, zamak I, 69.

28

Šejka, Traktat o slikarstvu, 23.

\section{9}

Milosavljević Ault, Skladište: Smisao i funkcija skaldišta u umetničkom

sistemu, 66.

30

Subotić, „Leonid Šejka: Podaci o ličnosti i delu“. 33

31

Šejka, Grad dubrište zamak I, II,I2

32

Šejka, Traktat o slikarstvu. I5 
šavanjima objekata". Nazivajući flašu flašom, suprotno od tipično dadaističkog metoda nazivanja objekata drugačijim nazivom, on želi da fiksira flašu, „da bezličnu, ma koju flašu, proglasi za flašu", istovremeno poništavajuči neka od njenih svojstava, na primer prozirnosti, bojeći je. Na slikama, s druge strane, posebno u seriji slikanih Mrtvih priroda, on predmete iz dela u delo ponavlja dajući im određena simbolična značenja, kreirajući „specijalan alfabet, moglo bi se reći klinasto ili hijeroglifsko pismo, čiji su konstitutivni elementi do kraja poznati samo njegovom tvorcu". ${ }^{24}$ Tako kaput vidi kao oklop, ljušturu, čašu kao predstavnika cilindričnih objekata i ponavlja in kao motiv u mnogim delima. I ovu aktivnost možemo prepoznati kao odabir te rekontekstualizaciju predmeta, sličnu onoj kada jedan selektovani predstavnik svoje vrste postaje delom kolekcije čudesa-slike sveta svog kreatora. Najzad, u ovom poimanju sveta kroz predmete, Šejka prihvata Joneskov moto o „Svetu, tom velikom rekvizitarijumu" (parafrazirajući ga u slici Multiplikacije), dok svoj slikarski razvoj vidi kao jednu „cik-cak izlomljenu liniju, možda spiralu", kojom ovaj umetnik luta dok stvara, poput renesansnog kolekcionara koji svojim sakupljanjem teži da zaokruži celinu i zaustavi tok vremena, poništavajući progres.

Ako kolekcionar ili kustos predmete uvodi u novu stvarnost, stvarnost koja funkcioniše u okvirima muzejske postavke i uspostavlja polisemične relacije među objektima, Šejka umetnost upravo koristi kako bi izgradio vlastitu stvarnost kao svojevrsnu kolekciju odabranih predmeta koji u njoj dobijaju novu moć i nova značenja. Najzad, i sliku nastalu 1956. koja prema Lidiji Merenik „manifestno pokazuje ako ne anticipiranje postmoderne, onda svakako mišljenje koje se kreće unutar istorijskog i civilizacijskog lavirinta simbola, amblema i značenja", ${ }^{25}$ naziva upravo Muzejska postavka. Predmeti, dakle, Šejki omogućavaju da spozna, odnosno sazna svet oko sebe, a „slika postaje jedno ogledalo koje odslikava svesadržavajući prostor", naglasiće Šejka (bivajući na tragu ideja Leonarda da Vinčija). Počevši upravo od 1956. godine, ovaj umetnik razvija sistem uokvirivanja predmeta na slici kvarturom, kako sam naziva okvir koji slika oko predmeta, naglašavajući zaseban svet u okviru kojeg postoje određene zakonitosti. ${ }^{26}$ „Htedoh da izvedem jednu zatvorenost za sebe, jedan svoj svet, koji će imati u ukupnosti odlike onog drugog, tako da sada mogu da ga posmatram, transponujem u neku umetnost ili filozofiju. Sistem kvarture ima svoj unutrašnji kauzalitet." 27 Obašnjavajući jasnu simboliku broja četiri, odnosno kvarture, on zapisuje: „(...) pitagorejski simbol u znaku broja četiri, simbol konkretnog prostora, odnosno simbol sveukupne materije. Kubični matematički prostor simboliše utemeljenu vladavinu četvorine, četvorine koja je smenila vladavinu trojstva. Iz kubičnog enterijera otvara se horizont sa četiri strane sveta, četiri osnovna stanja materije, sa četiri dimenzije prostora." 28 Sagledavajući svoje okruženje kao opredmećenu, otuđenu, urbanu prirodu prepunu proizvoda ljudskog rada, Šejka dakle reaguje predlažući ponovnu izgradnju sveta: „Svet mora da se upozna, ne da se ruši, da bi se na njegovim temeljima izgradio novi. Umetnički sistem kvarture podrazumeva slobodno i nesputano izražavanje, kao vid istraživanja, ispitivanja koje ima za cilj saznanje zakona koji vladaju u ovom svetu, a koje je vremenom dobijalo najrazličitije forme", zaključiće Angelina Milosavljević Ault oslanjajući se na Šejkine spise. ${ }^{29}$

Dok kreira sopstveni mikrokosmos tokom (umetničkih) aktivnosti, Šejka će i svoju ličnost videti kroz četiri uloge: Šejka Klasifikator, statističar zadužen za pitanja kosmogonije i fizike; Reg Talbot, fotograf zadužen za registracije, radi kvazifotografije; Leon Leš geolog i slikar; Leon van Kis (Kreacija iza Sinteze), slikar i pesnik, neko ko traži Zamak. „Ove ličnosti simbolizuju Šejkinu širinu duha, njegovo nepristajanje da se opredeli samo za jednu liniju stvaranja, samo za jedan isključivi način izražavanja. Skup ovih ličnosti metaforično pokazuje njega samog, kompleksno ispunjenog nezajažljivom glađu da sazna svet oko sebe i da nađe ne jednu, ne dve-već mnogo istovremenih mogućnosti izraza." , navešće Irina Subotić, ${ }^{30}$ a u daljem tekstu videćemo koliko još različitih izraza je Šejka imao tokom svog stvaralačkog istraživanja i sugerisati međusobnu povezanost svih ovih, naizgled potpuno oprečnih dela.

Najzad, haos đubrišta na kojem umetnik luta birajući predmete za svoju kolekciju, jeste ona prava, iskonska slika sveta, kao što je i naizgled neuređena zbirka čudesa zapravo otkrivala jasne zakonitosti u svetu u kojem priroda, čovekove tvorevine, nauka i umetnost funkcionišu uvek zajedno. „Rekao sam haos; to je bio samo prvi utisak. U stvari, sve je u strogom poretku, svaka radnja je tačno predviđena, svaki predmet ima svoje određeno mesto, svaki predmet je jedna mašina i sve zajedno sačinjava jedan sistem, jedan sklop neumoljive povezanosti, jednu mrežu, stostruki lanac uzroka i posledica, površinski razvučen i zaboden u tkivo, u meso prostornosti ili razapet u nizu vremenskog proticanja." 31

\section{ŠEJKIN KABINET ČUDESA \\ KROZ POVRATAK RENESANSNOM SLIKARSTVU I TRAŽENJE ZAMKA}

Još jedan argument zbog kojeg se pojam kabineta čudesa može primeniti kada je tumačenje Šejkinog opusa u pitanju, jeste odnos ovog umetnika prema renesansnom dobu i poimanju sveta karakterističnom za taj period.

U vremenu renesanse i postavljanju principa humanizma, on vidi ideal sveta najbliži stvarnim potrebama čoveka. Stoga se vraća načelima renesansnog slikarstva zapisujući: „Slika treba da bude što stvarnija stvarnost, što bliža životu, oblici slike treba da budu što sličniji oblicima prirode. Ali od svega toga treba da se formira ceo univerzum, unutrašnja i spoljašnja stvarnost slike može da bude samo iluzija stvarnosti prirode." 32 Savršena priroda, objasniće Šejka, jeste ona koja sadrži i nesavršeno, dok je ideal savršenstva prirode istovremeno i ideal savršenstva ličnosti. I ovim stavom ukazujući na potrebu da, nakon što istraži predmete koji ga okružuju, kroz svoje slikarstvo otelovi lični, unutrašnji mikroskosmos, Šejka će naglasiti: „Slikar je u samom sebi ponovo otkrio 
svoj unutrašnji duhovni svet, otkrio je, dakle, podudarnost svog unutrašnjeg duhovnog sveta i spoljašnjeg materijalnog sveta." ${ }^{33}$ Slika počinje upravo od subjekta, njegovog duha, da bi se prenela na slikarsko oko koje „obuhvata ceo univerzum", preuzeće Leonardovu ideju. ${ }^{34}$ Nadalje, povratak renesansnim načelima temporalnosti i totalnosti sveta, od velikog je značaja za razumevanje duhovnog, kako i Šejka navodi, „spiralnog" lutalaštva (koje je uvek, kao i kod renesansnog kolekcionara, nerazdvojno od onog fizičkog). Njemu je blisko stanovište Berđajeva da prihvatanje prošlosti znači odbijanje teorije napretka i svakog futurističkog koncepta društva i života. ${ }^{35}$ Stoga, veruje da napredak onemogućuje oslobađanje čoveka i da u oblasti duha i u stvaranju ne postoji pravolinijski napredak. „Izvedena iz njegovog dela i njegove pisane misli, ideja o napretku mogla bi se rezimirati rečima Andreasa Lisa da je to pre kao hod po periferiji kruga čija beskonačnost stvara utisak da neprestano idemo napred." ${ }^{36}$ Hodajući ovom kružnom putanjom, Šejka se vraća analizi segmenata renesansne slike.

Navedene ideje prepoznaju se prilikom analize serije radova sa temama enterijera, soba, odaja i terasa u kojima on prihvata načela, a neretko i teme renesansnog slikarstva. Ova serija predstavlja i „upućivanje ka Zamku“ ${ }^{37}$ ka tom neosvojivom idealu, višem cilju i krajnjoj liniji koju umetnik traži u svojim lutanjima kroz Grad i Đubrište. I ovi radovi mogu se razumeti, dakle, kao deo Šejkinih israživačkih lutanja kroz medij slikarstva i kroz analizu svojih prethodnika, slikara od renesanse do njegovog, modernog doba. Sam Traktat o slikarstvu neretko, kao i najzad, mnoga njegova likovna dela, izgledaju kao kolekcija, nabrajanje, klasifikacija i raspoređivanje odabranih umetnika u Šejki značajne kategorije.

Šezdesetih godina nastaju dakle serije slika soba poput: Soba Kuzanskog, Soba Lajbnica, Soba cara Ivana, Siva Soba, Kvadratna soba, ali i, prema mnogim autorima najznačajnija, odnosno rezime svih njegovih istraživanja: Odaja svetlozarnosti. Sobe i odaje, treba istaći, prostori su koji su renesansnom kolekcionaru služili kao kutak za kontemplaciju, mesto njegovih ličnih zbirki čudesa i umetnina. Šejkine sobe se kompozicionim jedinstvom, produbljenom perspektivom, osvetljenjem i temama vraćaju upravo renesansnim delima dok Šejka najzad i vidi najveće uzore među umetnicima ovog doba. Ispunjene predmetima poput starih mapa, škrinja, peščanih satova, kristala i planetarijuma, ove sobe svojom estetikom ali i prikazanim, odabranim semioforama upućiju na kolekcije umetnina i kurioziteta. One povremeno otkrivaju i čudesna bića ${ }^{38}$ i neočekivane i nepoznate sfere kao na Hronometriji Tlona (Istraživanju planete Tlon). Na temu ovog dela, rađenog tokom 1964. godine, nesumnjivo je uticala Borhesova zbirka priča Maštarije prevedena u Nolitovom izdanju na srpski jezik 1963. godine. U istoj je štampana i priča „Tlön, Uqbar, Orbis Tertius" koja je duboko impresionirala Šejku „kao neočekivani, dragoceni susret sa ličnošću mašte i bliskih duhovnih koordinata". Šejka se u to vreme već dugo bavio problemom predmeta, njegovim rastom, kao i zamišljenim podnebljima, te je i u Borhesovom delu prepoznao neka od svojih lutanja.
Slikajući njegov „Tlön" Šejka beleži: „Slika se može praviti kao enciklopedija jednog Tlona, zamišljene planete, tako da ostaje sve dotle fikcija, dok svet ne počne da se pretvara u Tlon" ${ }^{39}$, ovime takođe ukazujući na svoju potrebu za kreiranjem sveobuhvatne slike sveta u svojoj slici.

Istu težnju otkriće i motiv cadisa likovno predsavljen kao crni kvadrat u koji je upisan beli krug, ili kao crni krug u belom kvadratu, ređe elipsi ili trapezu, presečenom dijagonalama. Ova shema se često javlja kao element na crtežima koji pripadaju sistemu đubrišta, ali i na slikama soba ili kao samostalna kompozicija koja postaje, u kasnijem periodu oko 1967. do 1969. godine, vrlo religiozno, ritualno zamišljena sa elementima prikaza evharistije i često s jednom prostorno istaknutom, razorenom sferom, simbolom sveta. Dijagonalama se u kvadratu obrazuju četiri polja, dve trećine ostaju prazne, a jedna se naseljava predmetima-simbolima; svet je konačan, a samo jedna četvrtina mu je produžena u beskonačnost. Cadis, poput kvartura, ponovo odgovara simbolici broja četiri u čijem je znaku čitav svet. Suprotno đubrištu, odnosno skaldištima kojima je umetnik razmatrao problem brojnosti, nestalnosti, neodređenosti i beskonačnosti, cadis označava središte sveta, centrično i simetrično, početno stanje sveta. Ono se kao jezgro ponavlja na nizu slika i sugeriše konstantu, „postaje na taj način sastavni deo fatamorgane Zamka". ${ }^{40}$

Iz Šejkinih soba se tek ponegde nazire zdanje zamka, odnosno pre, samo terase zamka kojem umetnik i u svojim lutanjima gradom i đubrištem i u svojim spisima i istraživanjima teži. Kako Miodrag Protić naglašava: „Šejkine Sobe i Terase su projekcije-nikad svršene i nikad potpune-integralnog, beskonačnog: Zamka. A beskonačno ne može biti-konačno, stalno. " 41 "Terasa zamišljenog raja" predstavljena je u predelu koji i sam predstavlja sećanje na renesansne slike, „ispunjen svetlošću više duhovnom nego prirodnom"42. Prema Nikoli Dediću, Šejkina metafora Zamka prostor je izmirenja suprotnosti-mediala-nastalih usled destruktivnosti savremene evropske civilizacije u kojoj se celoviti subjekt gubi. Zamak je, upotrebiće Šejkine reči: "katedrala celovitosti duše". ${ }^{43}$ Za renesansnog kolekcionara zamak je bio realan prostor u koji će on neretko smestiti upravo zbirku čudesnih predmeta, svoju Wunderkammer. Ipak, kako Le Gof (Jacques le Goff) primećuje, zamkovi su dobili metaforičan, bajkoviti prizvuk u onom trenutku kada su izgubili svoju osnovnu funkciju, kada više nisu mogli poslužiti kao odbrambena utvrđenja jer je izum vatrenog oružja uspeo da prenebregne problem njihovog osvajanja. Ova rekontekstualizacija zamka kao funkcionalnog objekta u fantazam, sliku prividne sigurnosti, utočišta i bezbednosti onoga što se u njemu čuva, odmah izaziva asocijacije na predmet u muzeju, odnosno nađeni objekat u okviru umetničkog dela, u oba slučaja rekontekstualizovan predmet koji gubi svoju primarnu funkciju i postaje svojevrsni nosilac značenja koji će zauvek biti sačuvan. Ako je zamak (realna arhitektonska građevina) renesansnog kolekcionara težio nemogućem-da okupi sve znanje sveta na jedno mesto, otkrivajući duh 


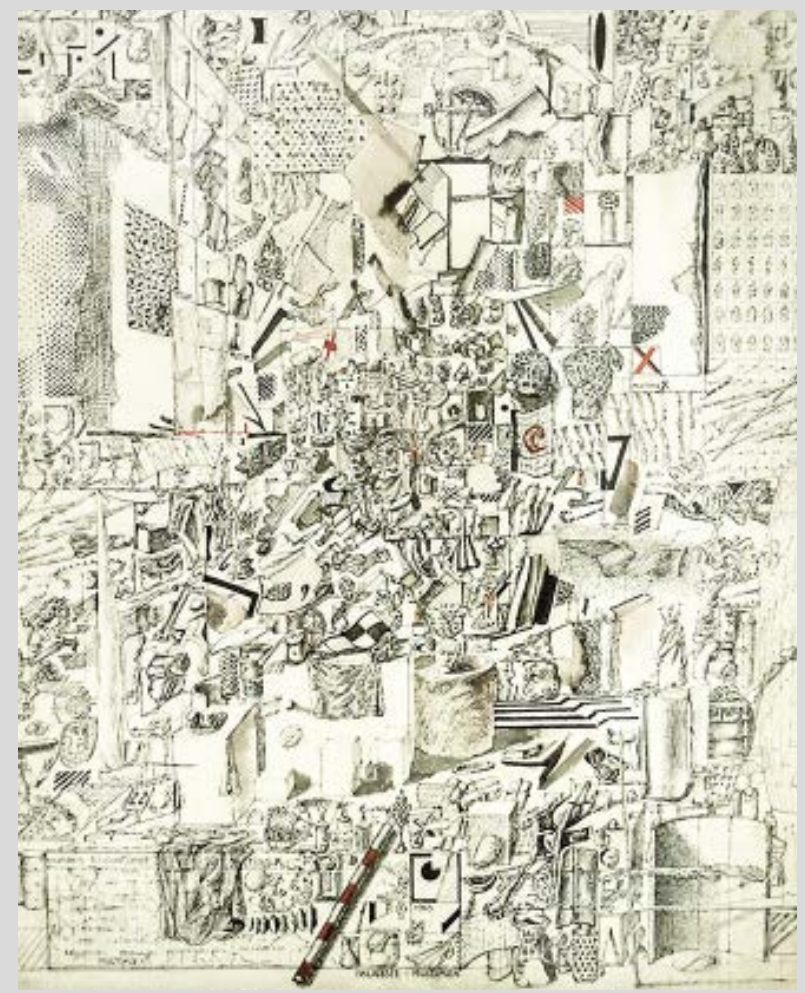

Leonid Šejka, Skladište Multipleks [Multiplex Warehouse], 1965., tuš akvarel / ink drawing, watercolor. (Soba Leonida Šejke, kolekcija Nenada Erića, katalog izložbe. Beograd: Fondacija Plavo, 2017./ Soba Leonida Šejke, the collecion of Nenad Erić, exhibition catalogue. Belgrade: Fondacija Plavo, 2017)

33

Isto, IO.

34

Isto, I9.

35

Prema: Protić, Leonid Šejka: Parabola o integralnom, 3-4.

36

Isto, 6 .

37

Subotić, „Leonid Šejka: Podaci o ličnosti i delu“, passim.

38

A čudesnim i mističnim Šejka se bavi i kroz svoje priče poput:

„Put“, „Priručnik veštice“, „Iskušenja sv. Antonija“, te se u svojim istraživanjima osvrće na Blejka, Poa, Kafku i Borhesa. 39

Subotić, „Leonid Šejka: Podaci o ličnosti i delu“, 37

40

Isto, 39 .

41

Protić, Leonid Šejka: Parabola o integralnom, I2.

42

Isto, 9 .

43

Dedić, Ka radikalnoj kritici ideologi je: od socijalizma ka postsocijalizmu, I75.

Ono što otelovljuje u likovnom delu kao potpuno drugačije izraze tokom svog istraživanja, Šejka i objašnjava u svom „Traktatu o slikarstvu“: „Ipak u samoj ličnosti, u subjektu, postoji spreg suprotnih sila, spreg dva oprečna zahteva. Jedan koji traži stvarnost u celini, drugi koji traži veliku množinu pojedinačnih obličja stvarnosti, svaki poseban oblik.", I3.

45

Šejka, Grad, dubriste zamak I, II7.

46

Isto, 82 . melanholičnog sakupljača koji nikada neće biti zadovoljan svojom zbirkom, odnosno čiji kabinet čudesa nikad neće biti potpun, onda je ranije pomenuti nadrealistički zamak takođe nedostižan na nivou razumevanja sveta potsvesnog, snova i čudesnog. Kod Leonida Šejke, uviđamo kako u njegovom literarnom, tako i u likovnom izrazu, Zamak je metafizička pojava, esencijalno nedostižna, dok je put ka istom, kao sveobuhvatnoj kolekciji kojom će konačno kreirati svoj mikrokosmos, konstantan. Jukstaponiranje potpuno različitih umetničkih izraza u ovom smislu samo je deo umetnikovih istraživačkih lutanja, ${ }^{44}$ a ovi začudni odnosi odgovaraju relacijama u koje kolekcionar dovodi predmete u svom kabinetu čudesa.

U svojoj Autobiografiji Šejka će najzad navesti sled svog interesovanja za nauke, rekavši da je prvo bio zainteresovan za astronomiju- ,materija prvobitnog oblika makroformata", pa za atomistiku - „to isto u mikroformatu", za biologiju - „drugi stupanj razvitka, organski svet“", pa za psihologiju- „čovek i njegova svest". ${ }^{45}$ Ako se vratimo razmišljanju o razvoju, odnosno različitim fazama Šejkinog likovnog stvaralaštva, onda i ovaj put od sagledavanja makrokosmosa, odnosno sveta i sistema vrednosti, preko mikrokosmosa, odnosno mehaničke prirode, predmeta koji ga okružuju i koje sakuplja i postavlja u različite značenjske odnose najzad težeći da kreira odraz svoje ličnosti, svoju sliku sveta, možemo posmatrati kao put ka ličnom kabinetu čudesa. Poslednju fazu „čoveka i njegove svesti” stoga možemo spoznati kao fazu u kojoj, nakon celog istraživačkog i kreativnog puta, Šejka kreira Skladišta i konstelacije malih predmeta koji ukazuju na značaj individualne slike sveta.

Konačni cilj Leonida Šejke jeste integralna slika u kojoj je svaki element, makar bio sličan nečem svakodnevnom, zapravo znak i simbol čovekovog univerzuma. „Svet slike tada više nije nadstvarnost nego panstvarnost, totalnost stvarnosti (...)." Težeći da konačno kreira ovu totalnu sliku sveta i tražeći semiofore svog doba, kako je i Tompson video „kreativnog pojedinca", Šejka je morao lutati đubrištem-prostorom beskrajnih mogućnosti. Njegov mikrokosmos otkriva nebrojeno mnogo začudnih odnosa među predmetima svakodnevice, ali i čitave zbirke posvećene objektima trajne vredosti-citate velikih umetnika, aproprirane segemente njihovog stvaralaštva, nizove simbola i znakova koje samo kolekcionar lično zna da rasporedi i sagleda u celini. Celokupno Šejkino stvaralaštvo predstavlja kako fizičko tako i mentalno lutalaštvo, ciklični povratak renesansnim načelima, te beskrajno istraživanje u želji da dostigne Zamak, da u okvirima svoje umetnosti otelovi lični kabinet čudesa.

Celokupno svoje stvaralaštvo, dakle, nesumnjivo je, Šejka promišlja kao jedinstvo u kojem traži sebe: „Neko će reći da se bavim raznim stvarima, da sam mnogostruk. Ali, ne ja se bavim jednom stvari i mnogostruk sam u lancu nedeljivog (...) Sistem je, najzad, istraživanje šta je, gde je smeštena moja stvorenost. U slikama, u tekstovima, u teoriji, u ovim pseudo-naučnim analizama, u povezanosti svega." 46 
Slikarstvo je najzad ovom umetniku „tehničko sredstvo da se čudesne i značajne pojave u prirodi označe, naglase i zabeleže" i ne možemo ga posmatrati odvojeno od Šejkine ličnosti koja ovu čudesnost nesumnjivo traži u svom okruženju i pokušava da predstavi u svom slikarskom prostoru. Stoga se ceo Šejkin put, svaka od njegovih faza i sistema mora sagledati kao neprekidno uspinjanje ka cilju (kako i sam umetnik vidi istraživanje materijalnog sveta), sakupljanje i raspoređivanje u kategorije, niz nekada veoma različitih međusobno jukstaponiranih predmeta u kolekciji, odnosno umetnikovih izraza u slici, crtežu i zapisima-koji predstavlja sliku sveta svog kreatora.

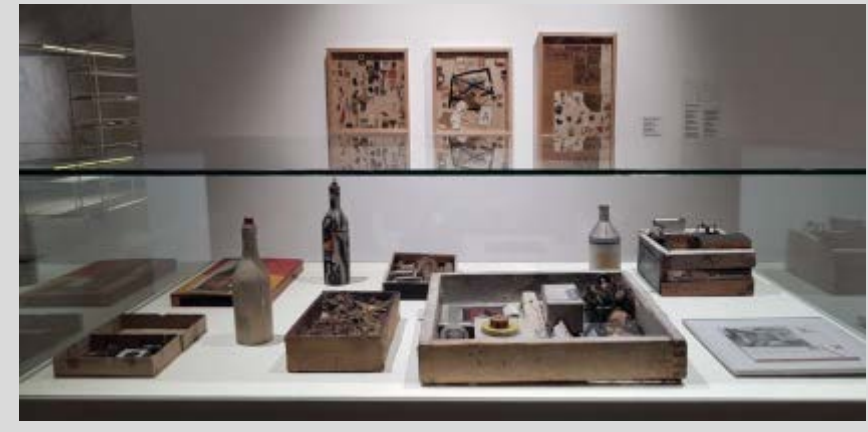

Kolaži i asamblaži Leonida Šejke, postavka Muzeja savremene umetnosti u Beogradu oktobra 2017. Na zidu desno: Opasnost dolazi sa đubrišta, kolaž, 1969. FOTO: Milena Jokanović / Collages and assemblages by Leonid Šjka, the permanent display of the Museum of Contemporary Art in Belgrade, October 20I7. On the wall, on the right: Opasnost dolazi sa dubrista [Danger Comes from Garbage Heap], collage, I969. PHOTO: Milena Jokanović 


\section{POPIS LITERATURE / BIBLIOGRAPHY}

Breton, Andre. Manifest nadrealizma, [1924], u: Tri manifesta nadrealizma. Kragujevac: Savremeni esej, ur: B.L. Lazarević, Dragomir Lazić, Ljubiša Đurić, 1972.

Breton, Andre. Nadja. Paris: Folio Plus, 1928.

Greenblatt, Stephen. Marvelous Possessions: The Wonder of the New World. Chicago: University of Chicago Press, 1991.

Danto, Arthur. "The Artworld", The Journal of Philosophy 61, br. 19 (Oct. 15, 1964): 571-584. American Philosophical Association Eastern Division Annual Meeting

Danto, Arthur. The Transfiguration of the Commonplace: a Philosophy of Art. Harvard University Press, 1981.

Dedić, Nikola. Ka radikalnoj kritici ideologije: od socijalizma ka postsocijalizmu. Beograd: Prodajnagalerija, Beograd-Novi Sad; Muzej savremene umetnosti Vojvodine, 2009.

Denegri, Ješa. Srpska umetnost 1950-2000: Pedesete. Beograd: Orion Art, 2013.

Dickie, George. Art and the Aesthetic: An Institutional Analysis. Ithaca NY: Cornell University Press, 1974.

Endt, Marion, "Reopening the Cabinet of Curiosities: Nature and the Marvellous in Surrealism and Contemporary Art", doktorska disertacija. University of Manchester, 2008.

Hooper-Greenhill, Eliean. Museums and Shapping of Knowledge. London-New York: Routledge, 1992.

Jokanović, Milena. "Memory on Cabinets of Wonders in Modern and Contemporary Art", 194-210. U: Dominique Poulot i Isidora Stanković (ur.). Discussing Heritage and Museums: Crossing Paths of France and Serbia, Choice of Articles from the Summer School of Museology Proceedings, Paris.October 2017, https://hicsa.univ-paris1.fr/ documents/pdf/Publi-cationsLigne/universite\%20ete_Belgrade_ Poulot/12_Jokanovic.pdf

Wunderkammer, Venice: Edizioni La Biennale - Electa Editrice, 1986.

Mauries, Patrick. Cabinets of Wonders. London: Themes and Hudson, 2013.

van Menš, Piter. Ka metodologiji muzeologije. Beograd: Muzej nauke i tehnike i Centar za muzeologiju i heritologiju Filozofskog fakulteta, 2016. [1992.].

Merenik, Lidija. Umetnost i vlast: srpsko slikarstvo 1945-1968. Beograd: Fond Vujičić kolekcija, 2010.

Metlić, Dijana. „U Šejkinoj zoni“. U: Zbornik seminara za studije moderne umetnosti 8. Beograd: Filozofski fakultet Univerziteta u Beogradu, 2012.

Milosavljević Ault, Angelina. Skladište: Smisao i funkcija skaldišta u umetničkom sistemu. Beograd: PUNKT, 2014.

Pomian, Krzsyzstof. "The Collection: between the Visible and the Invisible", 31-45. U: Collectors and Curiosities. Paris and Venice 1500-1800. Cambridge: Polity Press, 1990.

Protić, Miodrag B. „Leonid Šejka: Parabola o integralnom", 3-14. U: Katalog Retrospektivne izložbe 1932-1970. Beograd: Muzej savremene umetnosti, 1972.
Radić, Nenad. „Muzejski um Džozefa Kornela". U: Zbornik seminara za studije moderne umetnosti Filozofskog fakulteta u Beogradu. Beograd: Filozofski fakultet Univerziteta u Beogradu, 2009.

von Schlosser, Julius. Die Kunst- und Wunderkammern der Spätrenaissance: Ein Beitrag zur Geschichte des Sammelwesens. Leipzig: Verlag von Klinkhardt \& Biermann, 1908.

Sretenović, Dejan. Urnebesni kliker: Umetnost i politika beogradskog nadrealizma. Beograd: JP Službeni glasnik, 2016.

Subotić, Irina. „Leonid Šejka: podaci o ličnosti i delu", 15-45. U: Katalog Retrospektivne izložbe 1932-1970. Beograd: Muzej savremene umetnosti, 1972.

Šejka, Leonid. Traktat o slikarstvu. Beograd: Gradac, 2013. [1964.].

Šejka, Leonid. Grad, Đubrište, Zamak 1. Beograd: Niro „Književne novine", 1982.

Thompson, Michael. Rubbish Theory: the Creation and Destruction of Value. Oxford: Oxford University Press, 1979.

Vešler, Lorens. Kabinet čuda gospodina Vilsona. Beograd: Clio, 1999. 